\title{
Transcriptional activity of 3 ' deletion of the rat prolactin gene promoter
}

Salem El-jaffry ${ }^{1}$, I. Fehalbum ${ }^{1}$, Kh. Aldawy², Mohamed M.A. Hussein ${ }^{2}$ and Haytham. A. A ${ }^{2}$

(1)Department of Biochemistry, Faculty of Medicine, Tripoli, Libya

(2)Department of Biochemistry, Faculty of veterinary medicine, Zagazig University, Egypt

\section{A R T I CLE INFO}

Keywords:

prolactin, promoter, 3' deletion, Pit$1 / G H F-I$

\begin{abstract}
A B S T R A C T
Regulation of gene expression of prolactin gene still a point of study for many Scientifics so this work was designed to investigate the transcriptional activity of 3deletion of the rat prolactin gene promoter. A plasmid containing the rPrl gene promoter $(-423 /+38)$ was restricted at the unique EcoR1 site of 3' deletion of the ePrl promoter sequences in $\operatorname{rPrl}(-423 /+38)$. With suitable condition established prPrl $(-423 /+38)$ was EcoR1 restricted in preparative amounts and Bal31 treated for optimized time periods and the resulting DNA fragments pooled. The selected positives were then restricted with BamH1, Hind III and the presence of a Bam H1/ Hind III fragment $423 \mathrm{bp}$ verified by agarose gel electrophoresis. The results shows that the most proximal high affinity Pit-1/GHF-1 binding element is not an absolute requirement for GC cell specific transcriptional activity and that the Pit-1/GHF1 binding elements with sequence to -423 , is sufficient to confer relatively high transcriptional drive, in orientation independent manner.
\end{abstract}

(c) 2013 Publisher All rights reserved.

\section{INTRODUCTION}

Prolactin (PRL) is a neuroendocrine hormone of pituitary origin. However, in humans and primates, it is also expressed in extra-pituitary sites, including decidualized endometrium and circulating lymphocytes, and is reported to be involved in a wide range of biological pathways ${ }^{[1,2,3]}$. Several differences between human and rodent PRL was observed including the genomic locus arrangement, the pattern of gene expression in different tissues, and its biological role. The human PRL (hPRL) gene is transcribed under the control of two alternative promoters in a cell-specific manner.

The proximal (exon 1b) promoter drives expression in the pituitary gland and requires the pituitary-specific positive transcription factor (Pit)-1. In rodents, PRL acts mainly as an endocrine hormone, and its production is mostly restricted to the pituitary with a few exceptions ${ }^{[4,5,6]}$. Moreover, the PRL gene in rodents is part of an extended family of approximately 23 paralogues that have arisen by gene duplication and divergence ${ }^{[7]}$. The PRL receptor belongs to the cytokine receptor superfamily and is widely distributed throughout vertebrate tissues ${ }^{[8]}$. 
It is also expressed on the surface of lymphocytes, monocytes, neutrophils, natural killer cells, and thymic epithelial cells in both human and murine models ${ }^{[9,10]}$.

In humans, the prolactin locus exists in a gene poor region of the genome and consists of a single gene containing five coding exons, transcribed directly from a pituitary specific promoter, and a non- coding exon transcribed from an alternative promoter, which drives expression in non-pituitary tissues. By contrast, in rodents, gene duplication has generated a large family of prolactin genes, at a single locus, with independent expression profiles and independent functions ${ }^{[11]}$. Functional domains that mediate pituitary prolactin expression have been identified in the rat and human prolactin loci. A proximal promoter and distal enhancer are present in both species and share sequence homology ${ }^{[12,1]}$.

In the human locus, an additional upstream regulatory element, the superdistal enhancer, has been identified, although the functional significance of this element has yet to be fully characterized ${ }^{[13]}$. In the rat, the distal enhancer and proximal promoter have been shown to physically interact, generating a chromatin loop ${ }^{[14]}$. Rat prolactin gene expression is highly restricted to pituitary lactotroph cells and is induced by the cAMP-dependent protein kinase and this PKA effect requires at least one of the redundant pituitary-specific elements of the proximal rPRL promoter ${ }^{[15]}$.

In both species, pituitary prolactin expression is dependent on the Pit-1 transcription factor, a member of the POU homeodomain protein family ${ }^{[16,17]}$. Schuster et al., ${ }^{[18]}$ showed that a promoter/ receptor gene construct containing only the most proximal tissue specific binding element $(-75 /+38-C A T)$ was sufficient to drive CAT gene transcription in GH3 and GC cells. In this study we generated a small group of $3^{\prime}$ deletion of the proximal $\mathrm{rPrl}$ promoter $(-423 /+1)$ in order to stepwise delete the proximal tissue specific binding elements and study its effect on overall activity.

\section{Material and Methods}

A plasmid containing the $\mathrm{rPrl}$ gene promoter $(-423 /+38)$ was restricted at the unique EcoR1 site of 3 ' deletion of the ePrl promoter sequences in $\mathrm{rPrl}(-423 /+38)$. With suitable condition established prPrl $(-423 /+38)$ was EcoR1 restricted in preparative amounts and Bal31 treated for optimized time periods and the resulting DNA fragments pooled. These were blunted (using the klenow fragment of DNA-polymerase I and T4 DNA polymerase I), BamH1-linkers fitted and the plasmids relegated and transformed into E.coli strain HB101 (Fig 1).

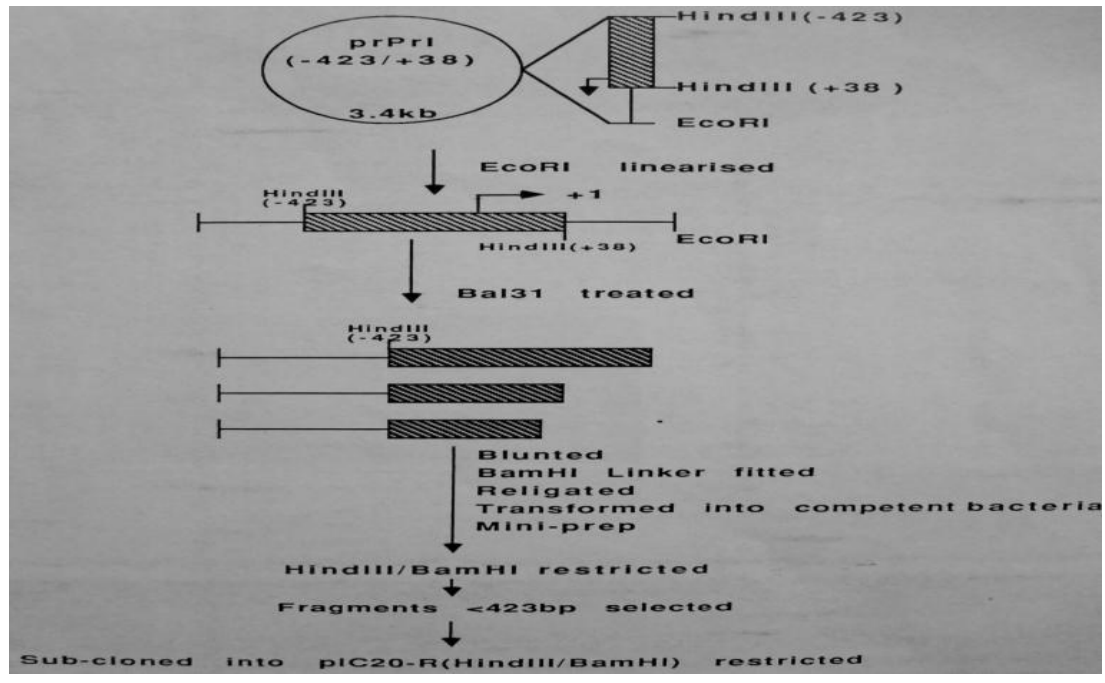

Fig 1. Strategy for the generation, characterization and subcloning, of 3' deletions of the rPrl promoter. 
The selected positives were then restricted with BamH1, Hind III and the presence of a Bam H1/ Hind III fragment $<423$ bp verified by agarose gel electrophoresis (Fig 2).
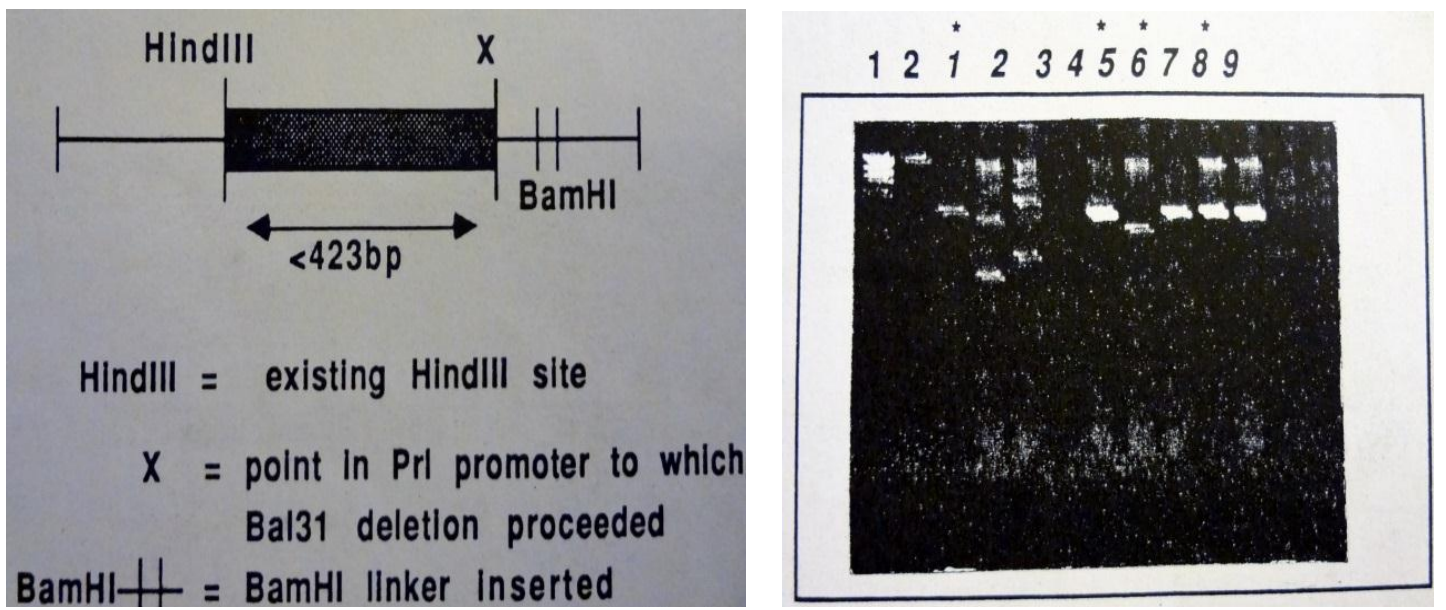

Fig 2: Bal31 deletion fragments of rPrl promoter from prPrl (-423/+38) Mini-preparation analysis of Bam H1 linker insertion. Note that nos: 1, 5, 6 and 8 are cut by BamH1. Lane 1: Hind III restricted phage $\lambda$ DNA. Lane 2: unrestricted prPrl (-423/+38)

\section{Results and Discussion:}

The alternative promoter which lies approximately $5.8 \mathrm{~kb}$ upstream of the pituitary transcription start site, adjacent to an additional noncoding exon 1a, directs transcription in extra-pituitary sites and is Pit-1 independent ${ }^{[19,20,21,22]}$. Activation of this promoter in the same tissue has occasionally been observed ${ }^{[23,24]}$.

The work of Schuster et al., ${ }^{[18]}$ highlighted the importance of the most proximal of the elements in the $\mathrm{rPrl}$ promoter which bind the pituitary specific transcriptional factor (Pit 1/GHF 1).

Nelson et al., ${ }^{[25]}$ had characterized four such binding elements in the proximal rPrl promoter but both studies recognized the high affinity with which the pituitary specific transcriptional factors bound to the most proximal site.

The plasmid constructs containing the mutated 3'-deleted rat prolactin promoter fragments in sense and antisense-orientation, were transfected into non pituitary cells (C6 and $\mathrm{CV}-1)$ and into rat prolactin cells (GH3 and GC). The transcriptional activity of the prolactin deleted promoter fragments was assayed by measuring the chloramphincol Acetyltransferase (CAT) enzyme activity conferred on the transfected cells. Extracts of the non-pituitary cells (C6 and CV-1) showed no CAT activity (Fig 3).

On transfection into GC cells (Fig 4) the construct containing the mutant fragment showed significant CAT activity in sense orientation (Lane 3) and in antisense orientation (Lane4).The mutant lacking the two most proximal Pit-1/ GHF-1 binding elements showed considerably lower CAT activity in sense orientation (Lane5) and in anti-sense orientation (Lane 6).

These results were confirmed by Rajnarayan et al., ${ }^{[15]}$ who study role of GHF-1 to mediate the protein kinase activation of the rPRL promoter and found that not only that GHF1/Pit-1 site is involved in mediating the PKA response, but also imply that a distinct and possibly ubiquitous factor functionally interacting with GHF-1 to modulate PKA beta regulation of the rPRL promoter. This finding suggests that the most proximal high affinity Pit-1/GHF-1 binding element is not an absolute requirement for GC cell specific 
Biochemistry letters, 8(2) 2013, Pages: 6-11

transcriptional activity and that the Pit-1/GHF-1 binding elements with sequence to -423 , is sufficient to confer relatively high transcriptional drive, in orientation independent manner.
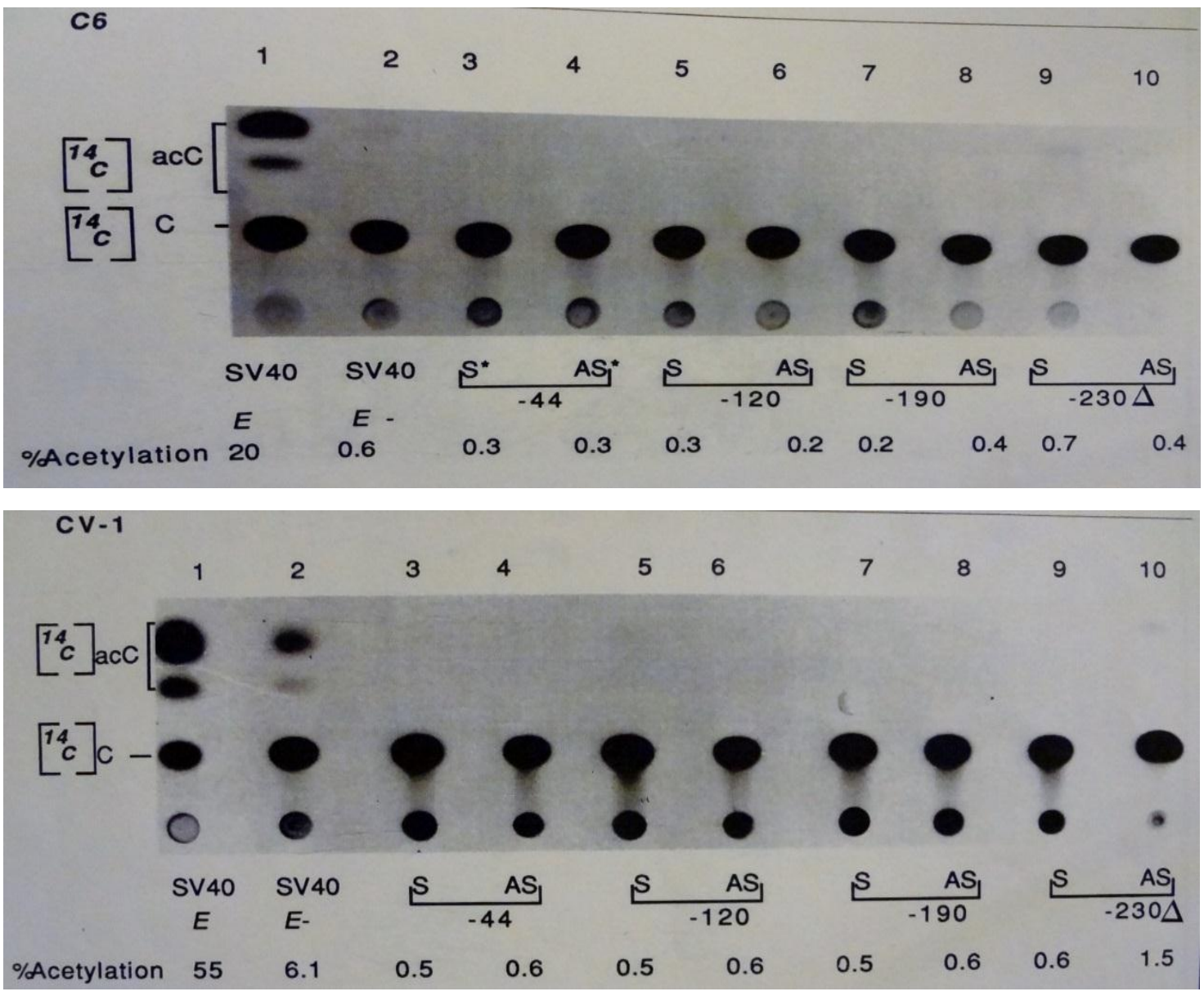

Fig 3: Tissue-specific expression of 3'deleted rPrl promoter fragments. The transcriptional activity as judged by CAT gene expression of the various rPrl-CAT 3' deletion mutants constructs on transient transfection into C6 and CV-1cells.

Shown is TIC analysis of $0.1 \mathrm{uCi}\left[{ }^{14} \mathrm{C}\right]$-chloramphenicol acetylation after incubation for $2 \mathrm{~h}$ with extracts prepared $48 \mathrm{~h}$ after cell transfection with Lane 1: pSV4OECAT, Lane 2: pSV4OE-CAT, and Lane 3-10: show the resulting CAT activity for rPrl -3' deletion mutant constructs ( $p S(-) p(\Delta)-C A T)$.

$* S=$ sense orientation

$A S=$ antisense orientation 
Biochemistry letters, 8(2) 2013, Pages: 6-11

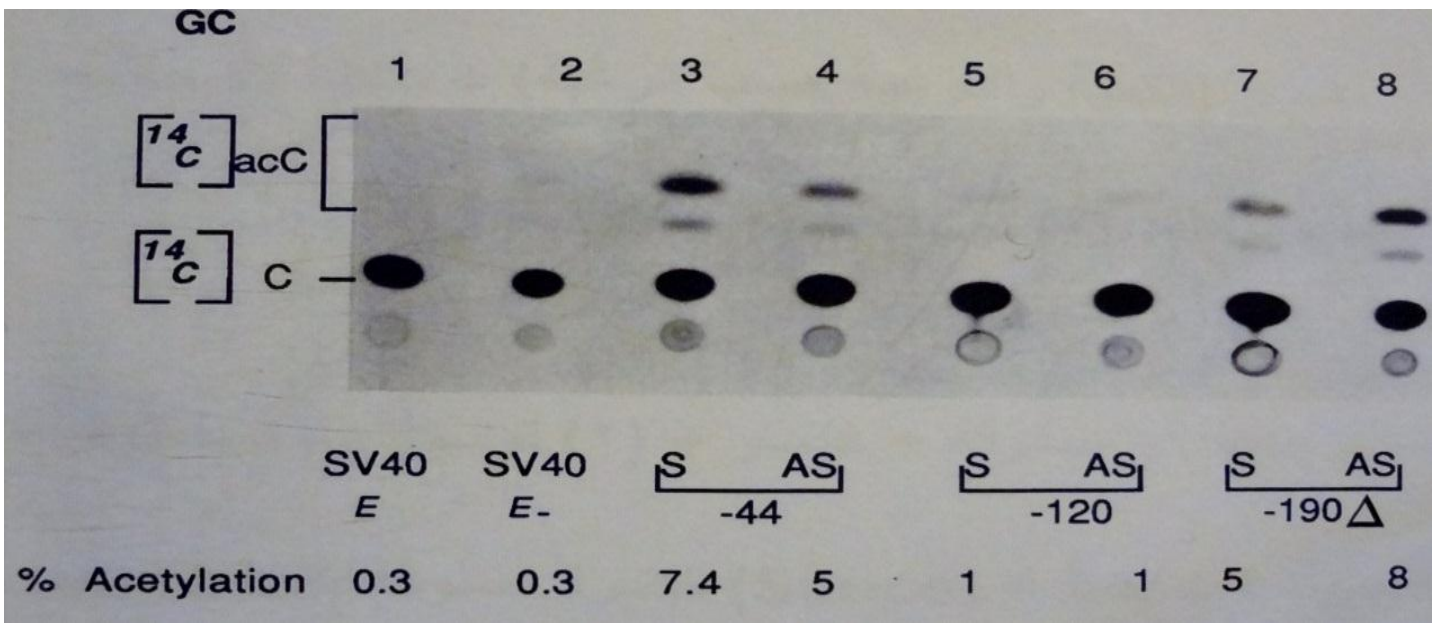

Fig 4: Tissue-specific expression of 3'deleted rPrl promoter fragments. The transcriptional activity as judged by CAT gene expression of the various rPrl-CAT 3' deletion mutants constructs on transient transfection into GCcells.

Shown is TIC analysis of $0.1 \mathrm{uCi}\left[{ }^{14} \mathrm{C}\right]$-chloramphenicol acetylation after incubation for $2 \mathrm{~h}$ with extracts prepared $48 \mathrm{~h}$ after cell transfection with Lane 1: pSV2ECAT, Lane 2: pSV2ECAT, and Lane 3-8: show the resulting CAT activity for rPrl -3' deletion mutant constructs $(p S(-) p(\Delta)-C A T)$.

$* S=$ sense orientation $\quad A S=$ antisense orientation

\section{References}

1- Ben-Jonathan N, LaPensee CR, LaPensee EW 2008: What can we learn from rodents about prolactin in humans? Endocr. Rev 29:1-41.

2- Bernichtein S, Touraine P, Goffin $\mathbf{V}$ 2010: New concepts in prolactin biology. $J$ Endocrinol 206:1-11.

3- Emera D, Casola C, Lynch VJ, Wildman DE, Agnew D, Wagner GP 2012: Convergent evolution of endometrial prolactin expression in primates, mice, and elephants through the independent recruitment of transposable elements. Mol Biol Evol 29:239-247.

4- Prigent-Tessier A, Tessier C, Hirosawa-Takamori M, Boyer C, Ferguson-Gottschall S, Gibori G 1999: Rat decidual prolactin. Identification, molecular cloning and characterization. J Biol Chem 274: 37982-37989.

5- Nevalainen MT, Valve EM, Ahonen T, Yagi A, Paranko J, Härkönen PL 1997: Androgen-dependent expression of prolactin in rat prostate epithelium in vivo and in organ culture. FASEB J 11: 1297-1307.

6- Maniates, T., Good bouro, S. and Fisher, J. K. 1987: Regulation of inducible and tissue specific gene expression. Science 235, 1237-1244.

7- Soares MJ 2004: The prolactin and growth hormone families: preg- nancy-specific hormones/cytokines at the maternal-fetal interface. Reprod Biol Endocrinol 2:51

8- Bole-Feysot C, Goffin V, Edery M, Binart N, Kelly PA 1998: Pro- lactin (PRL) and its receptor: actions, signal transduction pathways and phenotypes observed in PRL receptor knockout mice. Endocr Rev 19:225-268.

9- Gagnerault MC, Touraine P, Savino W, Kelly PA, Dardenne M 1993: Expression of prolactin receptors in murine lymphoid cells in normal and autoimmune situations. $J$ Immunol 150:5673-5681.

10- Reuwer AQ, van Eijk M, Houttuijn-Bloemendaal FM, vanderLoos CM, Claessen N, Teeling P, Kastelein JJ, Hamann J, Goffin V, von der Thüsen JH, Twickler MT, Aten J 
2011: The prolactin receptor is expressed in macrophages within human carotid atherosclerotic plaques: a role for prolactin in atherogenesis? J Endocrinol 208: 107-117.

11- Soares MJ, Konno T, Alam SM. 2007: The prolactin family: effectors of pregnancydependent adaptations. Trends Endocrinol Metab; 18: 114-121.

12- Peers B, Voz ML, Monget P, Mathy-Hartert M, Berwaer M, Belayew A, Martial JA. 1990: Regulatory elements controlling pituitary-specific expression of the human prolactin gene. Mol Cell Biol; 10: 4690-4700.

13- Van De Weerdt C, Peers B, Belayew A, Martial JA, Muller M. 2000: Far upstream sequences regulate the human prolactin promoter transcrip- tion. Neuroendocrinology; 71: 124-137.

14- Cullen KE, Kladde MP, Seyfred MA. 1993: Interaction between transcription regulatory regions of prolactin chromatin. Science; 261: 203- 206.

15- Rajnarayan S, Chiono M, Alexander L M and Gutierrez-Hartmann, A (1995): Reconstitution of protein kinase A regulation of the rat prolactin promoter in HeLa nonpituitary cells: identification of both GHF-1/Pit-1-dependent and -independent mechanisms. Molecular Endocrinology 9 (4):502-512.

16- Ingraham HA, Chen RP, Mangalam HJ, Elsholtz HP, Flynn SE, Lin CR, Simmons DM, Swanson L, Rosenfeld MG. 1988: A tissue-specific transcription factor containing a homeodomain specifies a pituitary phenotype. Cell; 55: 519-529.

17- Kerr J, Wood W, Ridgway EC. 2008: Basic science and clinical research advances in the pituitary transcription factors: Pit-1 and Prop-1. Curr Opin Endocrinol Diabetes Obes ; 15: 359-363.

18- Schuster, W. A., Treacy, M.N. and Martin, F. 1988: Tissue specific trans-acting factor interaction with proximal $\mathrm{rPrl}$ gene promoter sequence. EMBO, J., 7, 1721-1733.

19- Gellersen B, Kempf R, Telgmann R, Di-Mattia GE 1994: Non pituitary human prolactin gene transcription is independent of Pit-1and differentially controlled in lymphocytes and in endometrial stroma. Mol Endocrinol 8:356-373.

20- Berwaer M, Martial JA, Davis JR 1994: Characterization of an up- stream promoter directing extrapituitary expression of the human prolactin gene. Mol Endocrinol 8:635-642.

21- Lynch VJ, Tanzer A, Wang Y, Leung FC, Gellersen B, Emera D, Wagner GP 2008: Adaptive changes in the transcription factor HoxA-11 are essential for the evolution of pregnancy in mammals. Proc Natl Acad Sci USA 105:14928-14933.

22- Lynch VJ, Brayer K, Gellersen B, Wagner GP 2009: HoxA-11 and FOXO1A cooperate to regulate decidual prolactin expression: towards inferring the core transcriptional regulators of decidual genes. PLoS One 4:e6845.

23- Shaw-Bruha CM, Pirrucello SJ, Shull JD 1997: Expression of the prolactin gene in normal and neoplastic human breast tissues and human mammary cell lines: promoter usage and alternative mRNA splicing. Breast Cancer Res Treat 44:243-253.

24- Dagvadorj A, Collins S, Jomain JB, Abdulghani J, Karras J, Zell- weger T, Li H, Nurmi M, Alanen K, Mirtti T, Visakorpi T, Buben- dorf L, Goffin V, Nevalainen MT 2007: Autocrine prolactin pro- motes prostate cancer cell growth via Janus kinase-2-signal transducer and activator of transcription-5a/b signaling pathway. Endocrinology 148:30893101.

25- Nelson, C., Albert, V. R., Elsholtz, H. P., Lu, L. and Rosenfeld, M. 1988: Activation of cell-specific expression of the rat $\mathrm{GH}$ and prolactin genes by a common transcription factor. Science, 239, 693-697. 